\title{
Morphometry, age and growth of Siganus luridus Rüppell, 1828 and Siganus rivulatus Forsskål, 1775 (Siganidae) in the central Mediterranean (Libyan coast)
}

\author{
Morfometría, edad y crecimiento de Siganus luridus Rüppell, 1828 y Siganus rivulatus Forsskål, \\ 1775 (Siganidae) en la zona central Mediterránea (costa de Libia)
}

\author{
Esmaile Shakman ${ }^{1}$, Helmut Winkler $^{1}$, Rainer Oeberst ${ }^{2}$ and Ragnar Kinzelbach ${ }^{1}$ \\ ${ }^{1}$ General and Systematic Zoology, Universitätsplatz 2, D-18055 Rostock University, Germany \\ ${ }^{2}$ Institute for Baltic Sea Fisheries, Alter Hafen Süd 2, D-18069 Rostock, Germany \\ shugmanism@yahoo.com
}

\begin{abstract}
Resumen.- Algunos aspectos biológicos de las especies de siganidos en la costa de Libia, fueron estudiados en su morfometría, edad y crecimiento. Dos especies fueron recolectadas entre marzo 2005 y marzo 2006, 1.672 individuos de Siganus rivulatus de la costa oriental y 1.756 individuos de $S$. luridus de la costa occidental y el Golfo de Sirt. La edad de los especimenes capturados por cada especie se estimó mediante el análisis de los otolitos. Los resultados fueron comparados con los datos disponibles de diferentes localidades del Mediterráneo y del Mar Rojo. La edad de S. rivulatus osciló entre uno a seis años y para $S$. luridus fue de uno a siete años. Se observó una correlación positiva en las relaciones entre las distintas mediciones morfométricas y el tamaño corporal total de ambas especies. Las funciones de crecimiento de von Bertalanffy se estimaron como $\mathrm{L}_{\mathrm{T}}=35\left(1-\mathrm{e}^{-0.160(\mathrm{t}+1.04)}\right)$ y $_{\mathrm{T}}=30$ $\left(1-\mathrm{e}^{-0.213(t+0.784)}\right)$ para $S$. rivulatus y $S$. luridus, respectivamente. Las curvas de crecimiento de von Bertalanffy sugieren tasas de crecimiento más rápidas en $S$. rivulatus. La relación longitudpeso fue $\mathrm{W}_{\mathrm{T}}=0.233 \mathrm{~L}_{\mathrm{T}}^{2.82}($ S. rivulatus $) \mathrm{y} \mathrm{W}_{\mathrm{T}}=0.101 \mathrm{~L}_{\mathrm{T}}^{3.23}(S$. luridus). Siganus luridus tendría una tasa de crecimiento corporal más rápida que $S$. rivulatus, lo que podría indicar que está en un ambiente que le otorga mayor suministro de alimento.

Palabras clave: Biología, morfometría, edad, siganidos, Libia
\end{abstract}

\begin{abstract}
Some biological aspects of two siganid fish species from the Libyan coast were studied in terms of morphometry, age and growth. Two species were collected, between March 2005 and March 2006, comprising of 1,672 individuals of $S$. rivulatus from the eastern coastline and 1,756 individuals of $S$. luridus from the western coast and the Gulf of Sirt. The age of each species was estimated based on otoliths analysis and the results were discussed with data available from different areas of the Mediterranean and Red Seas. The age of $S$. rivulatus ranged from one to six years and $S$. luridus from one to seven years. The relationships between different morphometric measurements and total lengths for both species were positively correlated. Von Bertalanffy growth functions were estimated with $\mathrm{L}_{\mathrm{T}}=35\left(1-\mathrm{e}^{-0.160(\mathrm{t}+1.04)}\right)$ and $\mathrm{L}_{\mathrm{T}}=30(1-$ $\left.\mathrm{e}^{-0.213(\mathrm{t}+0.784)}\right)$ for $S$. rivulatus and $S$. luridus respectively. The von Bertalanffy growth curves suggest faster growth rates for $S$. rivulatus. The length-weight relationships were $\mathrm{W}_{\mathrm{T}}=0.233$ $\mathrm{L}_{\mathrm{T}}^{2.82}$ (S. rivulatus) and $\mathrm{W}_{\mathrm{T}}=0.101 \mathrm{~L}_{\mathrm{T}}^{3.23}$ (S. luridus). S. luridus would increase in weight at a more rapid rate than $S$. rivulatus, and this may point to a lake of suitable food supply for the $S$. rivulatus individuals in this region.
\end{abstract}

Key words: Biology, morphometry, age, siganids, Libya

and established in the eastern Mediterranean (Bariche 2005). Both species are now found as far west as Libya (Stirn 1970) and Tunisia (Ktari \& Ktari 1974). The Libyan coast has a varying topography with a wide range of habitats and environmental variables. Environmental factors such as salinity are known to strongly influence fish growth (Gaumet et al. 1995, Boeuf \& Payan 2001), and the optimal salinity for $S$. rivulatus is $35 \mathrm{psu}$ (Saoud et al. 2007). Some biological and ecological aspects of these species have already been studied in the eastern Mediterranean and Red Sea (Popper \& Gundermann 1975, Popper et al. 1979, Golani 1990, Bariche et al. 2003, 2004). In the eastern Mediterranean Sea in particular, different studies have highlighted the age and 
growth of these species. Along the Lebanese coast, Mouneimné (1978) has studied age and growth based on size structures. In the eastern Mediterranean Sea (Turkey) Bilecenoglu \& Kaya (2002) studied growth and age of $S$. rivulatus. Bariche (2005) also studied age and growth of Siganus species, which were captured along the Lebanon coast.

In this paper, we provide new information on the morphometry, age and growth of Siganus spp. from the Libyan coast, in the central Mediterranean. The aims of this study were to investigate (i) the relationships between different morphometric parameters and the population structures, (ii) the age and growth using the otolith analysis. The results are discussed with respect to observations of populations from the Red Sea and the eastern Mediterranean. Moreover, the study contributes to the overall knowledge of Siganus species in the Mediterranean Sea.

\section{Material and methods}

Samples for this study were collected monthly by trammel nets (inner mesh $26 \mathrm{~mm}$, outer mesh $120 \mathrm{~mm}$ ) in water depths between one meter and $30 \mathrm{~m}$ along the Libyan coast (Fig. 1). A total of 1,672 individuals of $S$. rivulatus were collected in the eastern Region (Tubruk, Benghazi) between March 2005 and February 2006. Additionally, a total of 1,756 individuals of S. luridus were caught in the Gulf of Sirt region (Musrata) and in the western region (Tripoli, Zwara) between March 2005 and March 2006. Samples of S. rivulatus were collected from habitats like sand, rock and grass, while $S$. luridus were collected from rocky habitats.

The samples were transported in ice boxes to the laboratory immediately after capture. Morphometric measurements (total length $\left(\mathrm{L}_{\mathrm{T}}\right)$, standard length, fork length, pre dorsal length, dorsal length, pre anal length, anal length, head length, eye diameter and pre eye length were measured according to Froese \& Pauly (2004). Total weight $\left(\mathrm{W}_{\mathrm{T}}\right)$ was measured with an accuracy of $0.1 \mathrm{~g}$. The meristic counts were counted for subsamples (45 S. rivulatus and $55 \mathrm{~S}$. luridus) taken randomly and the total number of vertebrae for each fish (28 individuals of $S$. rivulatus and 22 individuals of $S$. luridus) was determined from by X-ray radiography. Most individuals were sexed (1,229 individuals of $S$. luridus and 1,216 individuals of S. rivulatus). Both otoliths (Sagittae) were removed, cleaned in water and alcohol (ethanol) and stored for age determination after drying for further study. The otoliths were treated by xylol under reflected light to count the annual rings, but the growth rings were clearly visible when the whole otoliths were moistened with camomile

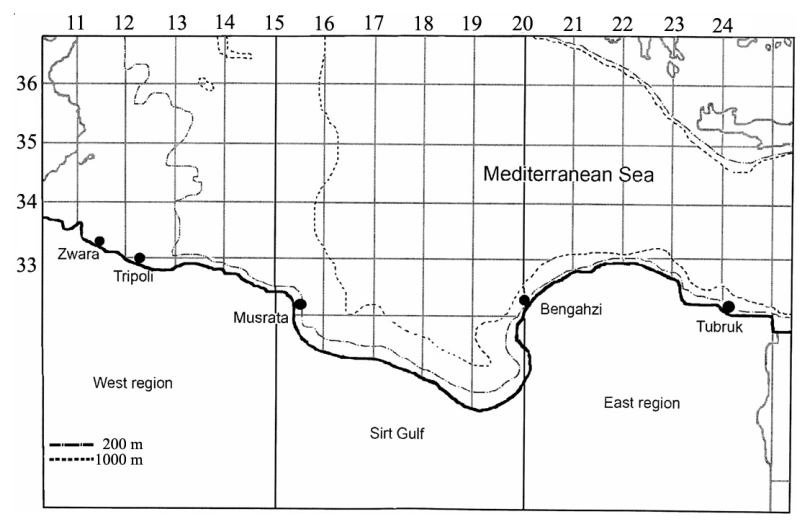

Figure 1

Map of Libyan coast line representing sampling areas

Mapa de la costa de Libia que muestra las zonas de muestreo

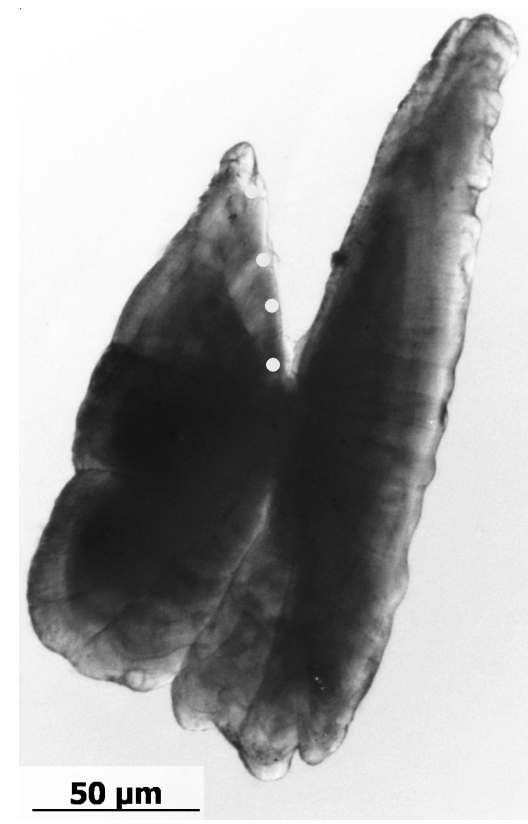

Figure 2

\section{An otolith from Siganus rivulatus showing the ageing (annual rings marked)}

Un otolito de Siganus rivulatus mostrando los anillos anuales de crecimiento

oil (Bariche 2005). Counts of rings and measurements were always performed in the same direction, from the nucleus to the edge of the otolith antirostrum (Fig. 2). The opaque and translucent zone was considered as the annual ring based on Bariche (2005). The counts were done by two independent readers (without checking the fish size); otoliths that were difficult to read were discarded. Back-calculation of total length, at the time where the production of hyaline zone was finished, is 
based on the relation between total length and the distance between the centre and edge of the otolith, using the equation: $\mathrm{L}_{\mathrm{I}}=\mathrm{L}_{\mathrm{N}}+\left(\mathrm{O}_{\mathrm{Ti}}-\mathrm{O}_{\mathrm{Tn}}\right)\left(\mathrm{L}_{\mathrm{N}}-\mathrm{L}^{*}\right) /\left(\mathrm{O}_{\mathrm{Tn}}-\mathrm{O}_{\mathrm{T}}^{*}\right)$, where $\mathrm{L}^{*}$ is the length of hatching, $\mathrm{O}_{\mathrm{T}}^{*}$ is the radius of the otolith of hatching, $\mathrm{L}_{\mathrm{N}}$ is the length of capture, $\mathrm{O}_{\mathrm{Tn}}$ is the radius of the otolith at capture, $\mathrm{L}_{\mathrm{I}}$ is the estimated length at time $\mathrm{Ti}$ and $\mathrm{O}_{\mathrm{Ti}}$ is the radius of the otolith at time Ti (Campana 1990).

Von Bertalanffy equation: $\mathrm{L}_{\mathrm{T}}=\mathrm{L}_{\infty}\left(1-\mathrm{e}^{-\mathrm{k}(\mathrm{t}-\mathrm{to})}\right)$ was used to quantify growth patterns of both species (Von Bertalanffy 1938), where $\mathrm{L}_{\mathrm{T}}$ is the total length at time $\mathrm{t} ; \mathrm{k}$ is a growth constant; $\mathrm{L}_{\infty}$ is the asymptotic length; and $\mathrm{t}_{0}$ describes the theoretical age where $\mathrm{L}_{\mathrm{T}}$ is zero (Ricker 1975). The model parameters $\mathrm{L}_{\infty}, \mathrm{k}$ and $\mathrm{t}_{0}$ were estimated by non linear regression analyses which are implemented in the statistical package Statgraphics (Statgraphics 2005). The phi-prime test ( $\left.\Phi^{\prime}\right)$ which reflects the overall growth performance was used to evaluate the reliability of the growth parameter (Pauly \& Munro 1984).

The length weight relationships were estimated from the allometric equation, $\mathrm{W}_{\mathrm{T}}=\mathrm{a} \mathrm{L}_{\mathrm{T}}{ }^{\mathrm{b}}$ (Ricker 1973) where $\mathrm{W}_{\mathrm{T}}$ is total body weight $(\mathrm{g}), \mathrm{L}_{\mathrm{T}}$ the total length $(\mathrm{cm})$, a and $\mathrm{b}$ are the coefficients of the functional regression between $\mathrm{W}_{\mathrm{T}}$ and $\mathrm{L}_{\mathrm{T}}$ and they were obtained using the Newton algorithm from the Microsoft $\AA$ Excel Solver routine. Relations between total length and the different morphometric parameters were described by the linear regression model Parameter $=\mathrm{a}+\mathrm{b} * \mathrm{~L}_{\mathrm{T}}$. Additionally, the coefficient of determination $\mathrm{R}^{2}$, and the standard error SE were estimated for each regression Statgraphics (2005). Generalized linear models (GLM) were used to analyse whether sex and catch area significantly influence the relations between length and the different morphometric parameters (Statgraphics 2005).

\section{Results}

\section{Total length frequency distribution}

The total length of all individuals $(n=1672)$ collected in this study ranged from 6.2 to $27.4 \mathrm{~cm}$ (Fig. 3) for $S$. rivulatus and from 10.2 to $25.5 \mathrm{~cm}$ (Fig. 4) for $S$. luridus ( $\mathrm{n}=1756$ ). The most frequent lengths were $15 \mathrm{~cm}$ for $S$. luridus and $18 \mathrm{~cm}$ for $S$. rivulatus. The range of total length, total weight and the mean and standard deviation are given by species in Table 1 .

\section{Relations of morphometric and meristic parameters}

Linear regression model was detected as the most appropriate model for describing the relations between morphometric parameters. Pooled data were used for the estimation of the regression parameters because GLM analyses where sex, area and month were used as

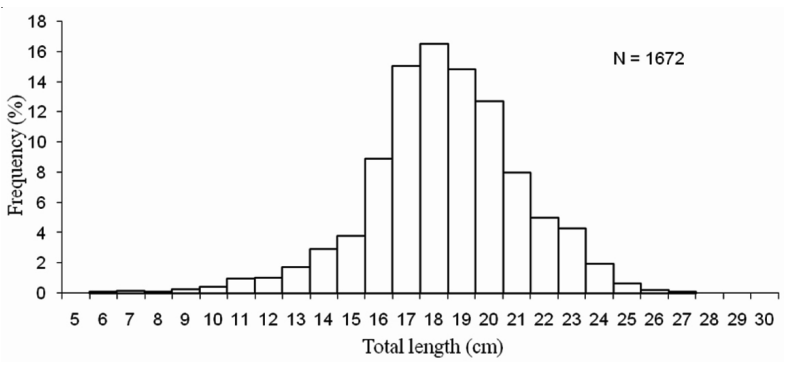

Figure 3

Length frequency distribution of Siganus rivulatus collected from March 2005 to February 2006 from the eastern part of the Libyan coast.

(N: number of specimens)

Distribución de frecuencias de la longitud total de Siganus rivulatus recogidos a partir de marzo de 2005 a febrero de 2006, de la parte oriental de la costa de Libia.

( $\mathrm{N}$ : número de especimenes)

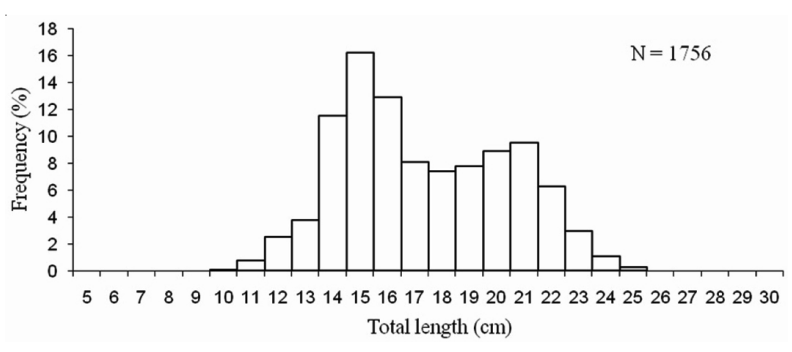

Figure 4

Length frequency distribution of Siganus luridus collected from March 2005 to March 2006 from the Sirt gulf and western part of the Libyan coast. ( $N$ : number of specimens)

Distribución de frecuencias de la longitud total de Siganus luridus recogidos a partir de marzo de 2005 a marzo de 2006, del golfo de Sirt y parte occidental de la costa de Libia. (N: número de especimenes)

categorical parameter have shown that their effects were not significant $(P>0.05)$. The regression parameters intercept (a) and slope (b) of the different relations morphometric parameter $=\mathrm{a}+\mathrm{b} * \mathrm{~L}_{\mathrm{T}}$ are given by species in Table 2.

\section{The total length-weight relationships}

The total length-weight-relations of both species are given in Figs. 5 and 6, which also contain the parameter of the multiplicative regression model together with the number of datasets $(\mathrm{N})$, the coefficient of determination $\mathrm{R}^{2}$ and the standard error (SE). Data of males and females were 
Table 1

Total length and total weight for Siganus rivulatus and S. luridus in the Libyan coast (Min: minimum, Max: maximum, Mean \pm SD: standard deviation and result of ANOVA, $P$ : statistical probability

Longitud y peso total de Siganus rivulatus y S. luridus en la costa de Libia (Min: mínimo, Max: máximo, Mean+SD: desviación estándar y resultado del ANOVA, $P$ : probabilidad estadística

\begin{tabular}{cccccccc}
\hline \multirow{2}{*}{ Parameter } & \multicolumn{9}{c}{ Siganus rivulatus } \\
& \multicolumn{2}{c}{ Female } & \multicolumn{2}{c}{ Male } & \multicolumn{2}{c}{ Pooled fish } \\
\cline { 2 - 8 } & Min-Max & Mean \pm SD & Min-Max & Mean \pm SD & $P$-value & Min-Max & Mean \pm SD \\
\hline $\mathrm{L}_{\mathrm{T}}(\mathrm{cm})$ & $6.2-27$ & $18.98 \pm 2.9$ & $6.3-26.5$ & $18.8 \pm 2.7$ & $>0.05$ & $6.2-27.4$ & $18.78 \pm 2.82$ \\
$\mathrm{~W}_{\mathrm{T}}(\mathrm{g})$ & $6.6-268.8$ & $101.02 \pm 33.9$ & $3.1-258.1$ & $97.22 \pm 38.2$ & $>0.05$ & $3.1-268.8$ & $96.16 \pm 39.7$ \\
& & \multicolumn{2}{c}{ Siganus luridus } \\
$\mathrm{L}_{\mathrm{T}}(\mathrm{cm})$ & $11.5-25.5$ & $17.9 \pm 3.12$ & $10.2-25.3$ & $17.78 \pm 3.12$ & $>0.05$ & $10.2-25.5$ & $17.75 \pm 3.03$ \\
$\mathrm{~W}_{\mathrm{T}}(\mathrm{g})$ & $29.3-406$ & $127.22 \pm 75.1$ & $25-326.4$ & $122.7 \pm 66.5$ & $>0.05$ & $25-406$ & $122.4 \pm 69.4$ \\
\hline
\end{tabular}

Table 2

Parameters intercept (a) and slope (b) of the linear regression, coefficient of determination ( $\mathbf{R}^{2}$ ) and standard error (SE) for different morphometric measurements of Siganus rivulatus and $S$. luridus in relation to total length $\mathrm{L}_{\mathrm{T}}$ and some meristic counts of specimens from the Libyan coast (March 2005 and March 2006) (N: number of specimens)

Parámetros de la regresión lineal, interceptar (a) y pendiente (b), coeficiente de determinación ( $\mathrm{R}^{2}$ ) y error estándar (SE) para diferentes mediciones morfométricas de Siganus rivulatus y S. luridus en relación con la longitud total (LT) y algunos conteos merísticos de ejemplares de la costa de Libia (marzo de 2005 y marzo de 2006) (N: número de especimenes)

\begin{tabular}{|c|c|c|c|c|}
\hline \multirow[t]{2}{*}{ Parameter $(\mathbf{c m})$} & \multicolumn{4}{|c|}{ Siganus rivulatus $(\mathrm{N}=\mathbf{5 0 9})$} \\
\hline & $\mathbf{a}$ & $\mathbf{b}$ & $\mathbf{R}^{2}$ & SE \\
\hline Standard length & 0.530 & 0.738 & 0.98 & 0.308 \\
\hline Fork length & 0.528 & 0.904 & 0.99 & 0.238 \\
\hline Body width & -0.388 & 0.288 & 0.90 & 0.269 \\
\hline Dorsal fin length & -0.014 & 0.552 & 0.95 & 0.336 \\
\hline Anal fin length & 0.524 & 0.302 & 0.88 & 0.229 \\
\hline Head length & 0.637 & 0.151 & 0.79 & 0.121 \\
\hline Eye diameter & 0.472 & 8.567 & 0.44 & 0.094 \\
\hline Vertebras column & & \multicolumn{3}{|c|}{21 to 22 Vertebras } \\
\hline \multirow[t]{2}{*}{ Meristic counts (average) } & & \multicolumn{3}{|c|}{$\mathrm{D}, \mathrm{XIV}+10 ; \mathrm{A}, \mathrm{VII}+8-10 ; \mathrm{V}, \mathrm{I}+3+\mathrm{I}$} \\
\hline & & \multicolumn{3}{|c|}{ Siganus luridus $\quad(\mathrm{N}=593)$} \\
\hline Standard length & 0.092 & 0.776 & 0.96 & 0.454 \\
\hline Body width & -0.767 & 0.382 & 0.93 & 0.307 \\
\hline Dorsal fin length & 0.068 & 0.583 & 0.96 & 0.356 \\
\hline Anal fin length & 0.596 & 0.322 & 0.90 & 0.322 \\
\hline Head length & 0.428 & 0.167 & 0.87 & 0.195 \\
\hline Eye diameter & 0.127 & 13.40 & 0.72 & 0.082 \\
\hline Vertebras column & & \multicolumn{3}{|c|}{22 Vertebras } \\
\hline Meristic counts (average) & & \multicolumn{3}{|c|}{$\mathrm{D}, \mathrm{XIV}+10 ; \mathrm{A}, \mathrm{VII}+8-9 ; \mathrm{V}, \mathrm{I}+3+\mathrm{I}$} \\
\hline
\end{tabular}




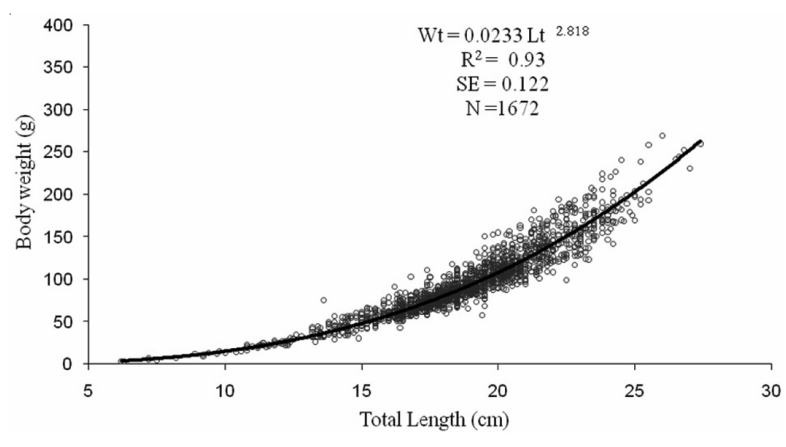

Figure 5

The length-weight relationship for Siganus rivulatus ( $N$ - number of samples, $R^{2}$ - coefficient of determination, SE - standard error)

La relación longitud-peso para Siganus rivulatus $\left(\mathrm{N}\right.$ - el número de muestras, $\mathrm{R}^{2}$ - coeficiente de determinación, SE - error estándar)

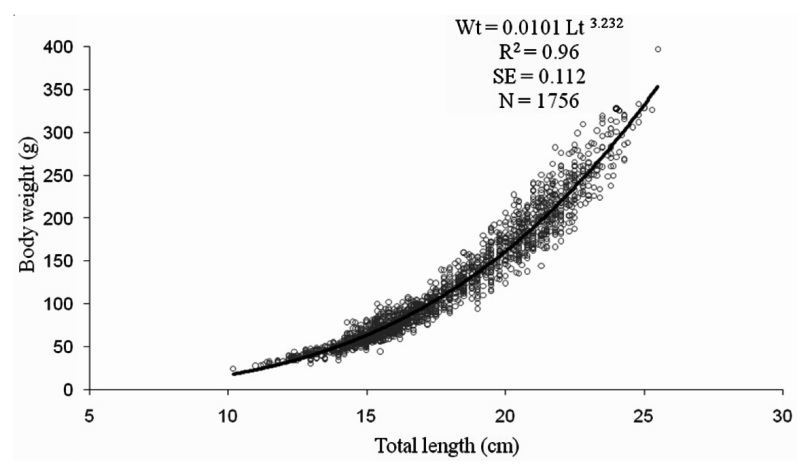

Figure 6

The length-weight relationship for Siganus luridus ( $N$ - number of samples, $R^{2}$ - coefficient of determination, $\mathrm{SE}$ - standard error)

Relación longitud-peso para Siganus luridus $\left(\mathrm{N}\right.$ - el número de muestras, $\mathrm{R}^{2}$ - coeficiente de determinación, SE - error estándar)

pooled because separated regression models did not significantly differ $(P=0.108$ for $S$. rivulatus and $P=$ 0.770 for $S$. luridus). $S$. rivulatus has a negative allometric growth with an exponent of 2.8. In contrast to this growth of $S$. luridus is positive allometric with an exponent of 3.2.

\section{The age composition and growth}

The age distribution of samples ranged from I to VI years for $S$. rivulatus and from I to VII years for S. luridus, based on the results of otolith reading (Fig. 7). The age group IV was dominant $(29.8 \%)$ for $S$. rivulatus, followed by age groups II (20.2\%), III (17.9\%), V (16.7), I (8.3)

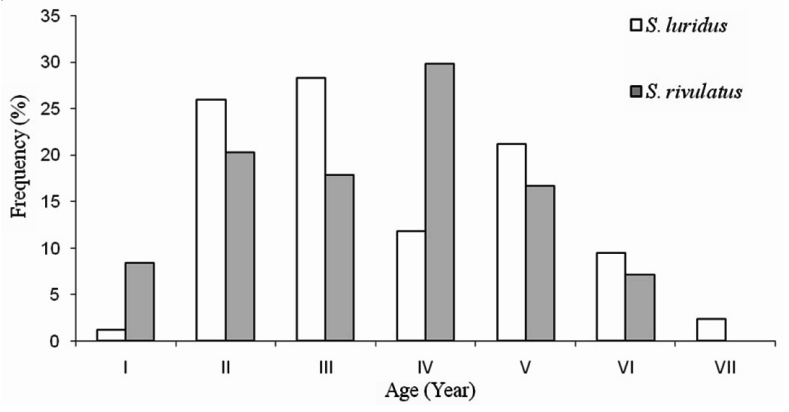

Figure 7

Relative frequency of the age of Siganus rivulatus and Siganus luridus in the Libyan coast

Frecuencia relativa de la edad de Siganus rivulatus y Siganus luridus en la costa de Libia

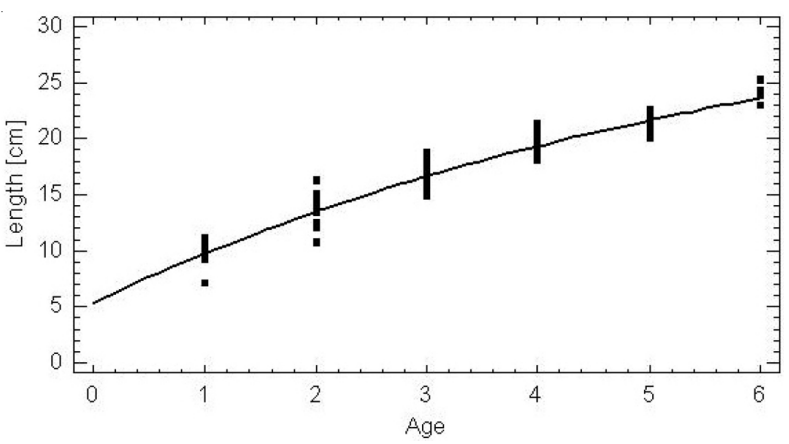

Figure 8

The von Bertalanffy growth curve for Siganus rivulatus in the Libyan coast

Curva de crecimiento de von Bertalanffy para Siganus rivulatus en la costa de Libia

and VI (7.1\%). Age group III was dominant (28.2\%) for S. luridus, followed by age groups II $(25.9 \%)$, V (21.2\%), IV (11.8\%), VI (9.4\%), VII (2.4) and I (1.2\%). Individuals of age group 0 of both species were not found in any samples. The growth of both species was described by the von Bertalanffy model based on the back-calculated length at age data (Figs. 8 and 9). The estimated growth functions were:

$$
\begin{gathered}
\mathrm{L}_{\mathrm{T}}=35.0 \mathrm{~cm}\left(1-\mathrm{e}^{-0.16(\mathrm{t}+1.04)}\right) \text { for } S \text {. rivulatus and } \\
\mathrm{L}_{\mathrm{T}}=30.0 \mathrm{~cm}\left(1-\mathrm{e}^{-0.21(\mathrm{t}+0.78)}\right) \text { for } S \text {. luridus }
\end{gathered}
$$

The asymptotic standard errors of the parameter of the growth curves are $\mathrm{s}\left(\mathrm{L}_{\infty}\right)=4.62, \mathrm{~s}(\mathrm{k})=0.04$ and $\mathrm{s}\left(\mathrm{t}_{0}\right)=$ 0.029 for $S$. rivulatus and $\mathrm{s}(\mathrm{L})=2.57, \mathrm{~s}(\mathrm{k})=0.05$ and $\mathrm{s}\left(\mathrm{t}_{0}\right)=0.35$ for $S$. luridus . 


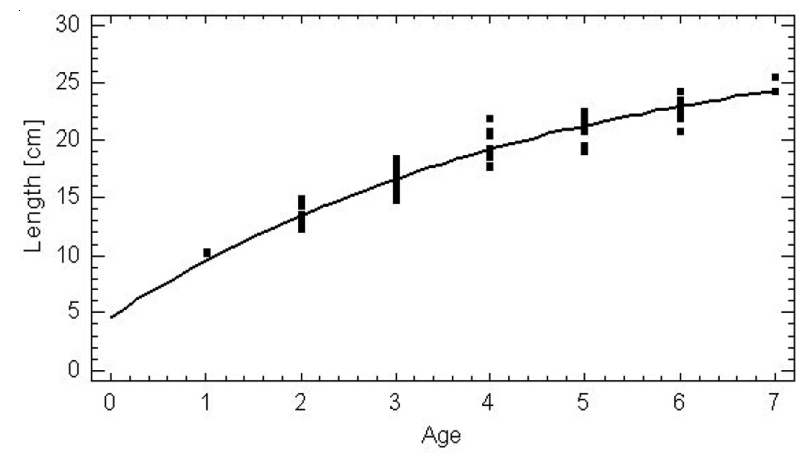

Figure 9

The von Bertalanffy growth curve for Siganus luridus in the Libyan coast

Curva de crecimiento de von Bertalanffy para Siganus luridus en la costa de Libia

Growth in both species is similar ( $\mathrm{K}=0.16$ for $S$. rivulatus and $\mathrm{K}=0.21$ for $S$. luridus), and a maximum theoretical length of $35.0 \mathrm{~cm}$ and $30.0 \mathrm{~cm}$ for $S$. rivulatus and $S$. luridus, respectively, which is supported by the values of the phi-prime ( $\left.\Phi^{\prime}\right)$ of 2.29 for $S$. rivulatus and 2.28 for S. luridus.

The results based on the weight were:

$$
\begin{gathered}
\mathrm{W}_{\mathrm{T}}=424.3(\mathrm{~g})\left(1-\mathrm{e}^{-0.10(\mathrm{t}+1.18)}\right) \text { for } S \text {. rivulatus } \\
\mathrm{W}_{\mathrm{T}}=525.9(\mathrm{~g})\left(1-\mathrm{e}^{-0.13(\mathrm{t}+1.44)}\right) \text { for } S \text {. luridus }
\end{gathered}
$$

The asymptotic standard errors of the parameter of the growth curves are $\mathrm{s}\left(\mathrm{W}_{\infty}\right)=248, \mathrm{~s}(\mathrm{k})=0.08$ and $\mathrm{s}\left(\mathrm{t}_{0}\right)$ $=0.16$ for $S$. rivulatus and $\mathrm{s}\left(\mathrm{L}_{\infty}\right)=213, \mathrm{~s}(\mathrm{k})=0.08$ and $\mathrm{s}\left(\mathrm{t}_{0}\right)=0.315$ for $S$. luridus.

Growth in both species is similar $(\mathrm{K}=0.10$ for $S$. rivulatus and $\mathrm{K}=0.13$ for $S$. luridus), and a maximum theoretical weight of $424.3 \mathrm{~g}$ for $S$. rivulatus and $525.9 \mathrm{~g}$ for S. luridus.

\section{Discussion}

Siganus rivulatus and S. luridus are common commercial fishes in the Levantine basin (Golani 1993). They have rapidly become two of the most abundant fishes ever since they were first recorded along the Libyan coast in 1970 (Stirn 1970). Both siganids have expanded their distribution and become commercially important along the Libyan coast (Shakman \& Kinzelbach 2007).

The most abundant size class ( $18 \mathrm{~cm} S$. rivulatus, 15 $\mathrm{cm} S$. luridus) is composed of fish that have already reproduced $(12.9 \mathrm{~cm}$ for females and $12.8 \mathrm{~cm}$ for males of $S$. luridus, while $14.1 \mathrm{~cm}$ for females and $13.5 \mathrm{~cm}$ for males of $S$. rivulatus) (unpublished data). The effects of sex, area and month were not significant on the size of species. The relationship between morphometric measurements and total length was positive for both species (Table1), which is usually the case for other similar fish species. In addition there was no significant difference in the meristic counts of individuals of different sizes within the same species. Golani (1990) reports that the change in meristic counts between Red Sea and Mediterranean populations is a combination of shifting and/or shortening of the spawning seasons and the different temperature regimes in the two seas.

The length-weight relationships can be used for forecasting both the potential yield and determining the most favourable size of capture to obtain optimum yield; these management parameters are directly related to the weight of the fish (Suresh et al. 2006). Actually, when the $b=3$ the relationship is isometric, positive allometric $(b>3)$ or negative allometric $(b<3)$ (Spiegel 1991). In general, b values of fish are closer to 3, despite the many variations of fish forms (King 1996). The exponent of the multiplicative regression model (b value) of $S$. rivulatus was 2.8, which shows that the growth is lightly isometric (Ricker 1975). Similar results were found for the Red Sea population (El-Gammal 1988) and in the southeastern Mediterranean (Egyptian coast) (Abdallah 2002). Slightly different results have been observed in the Red Sea and other parts of the Mediterranean (Table 3 ) however this difference is certainly due to different physiological and environmental conditions such as temperature, which vary with geographical locations. Also, it is well recognized that the functional regression «b» value represents the body form, and it is directly related to the weight affected by ecological factors such as temperature, food supply, spawning conditions and other factors, such as sex, age, fishing time and area and fishing vessels (Ricker 1973). The b value of S. luridus was 3.2, which describes a slightly positive allometry in growth, similar to results from the south eastern and eastern Mediterranean Sea (Abdallah 2002, Bariche 2005).

Age is one parameter necessary to assess population dynamics and the state of exploited resources (Allain \& Lorance 2000). Both species are long lived; the maximum age of $S$. rivulatus was 6 years and for $S$. luridus 7 years (Fig. 7). Different results have been found in the Red Sea and Mediterranean Sea, which partly used different methods of ageing. For example, Bariche (2005) reports a maximum age of 6 years for both siganid species from the Lebanese coast, based on annual ring counting. This is similar to the presented results of S. rivulatus and one year less than the presented results for $S$. luridus. This variation is most likely due to a different maximum length 


\section{Table 3}

Length-weight relationships and size range of sampled individuals from the present study and the literature for Siganus rivulatus and $S$. luridus; a and b parameters are estimated by relationship $W_{T}=a L_{T}{ }^{b}$. $R^{2}$ is coefficient of correlation and $\mathrm{N}^{0}$ is number of specimens. $\mathrm{M}$ : males, F: females, $\mathrm{P}$ : pooled females and males. Unit of size range in (cm) and weight in (g)

Relaciones de longitud-peso con el tamaño muestral de individuos de este estudio y de otras fuentes bibliográficas para Siganus rivulatus y S. luridus; a y b son los parámetros estimados por relación $\mathrm{W}_{\mathrm{T}}=\mathrm{a} \mathrm{L}_{\mathrm{T}}{ }^{\mathrm{b}} \cdot \mathrm{R}^{2}$ es coeficiente de correlación y $\mathrm{N}^{\mathrm{o}}$ es el número de especímenes. M: machos, F: hembras, P: hembras y machos agrupados. Unidad de límites de tamaño en (cm) y peso (g)

\begin{tabular}{|c|c|c|c|c|c|c|c|}
\hline Area & Species & Sex & a & b & $\mathbf{R}^{2}$ & No. & Size \\
\hline \multicolumn{8}{|c|}{ Red Sea } \\
\hline Ghardaqa (Egypt) & S. rivulatus & M & $12.33 \times 10^{-3}$ & 2.84 & 0.99 & 114 & $x$ \\
\hline El-Gammal (1988) & & $\mathrm{F}$ & $11.32 \times 10^{-3}$ & 2.84 & 0.99 & 137 & $x$ \\
\hline Jeddah (Saudi Arabia) & S. rivulatus & $P$ & $10.86 \times 10^{-3}$ & 3.07 & $\times$ & 898 & $11-30$ \\
\hline \multicolumn{8}{|l|}{ Hashem (1983) } \\
\hline \multicolumn{8}{|c|}{ Mediterranean Sea } \\
\hline Batrun (Lebanon) & S. rivulatus & M & $2 \times 10^{-6}$ & 3.32 & 0.95 & 98 & $12.7-13.2$ \\
\hline \multirow{5}{*}{ Bariche (2005) } & & $\mathrm{F}$ & $1 \times 10^{-5}$ & 3.01 & 0.96 & 93 & $12.6-26.7$ \\
\hline & & $P$ & $1 \times 10^{-5}$ & 3.04 & 0.99 & 781 & $2.48-26.7$ \\
\hline & S. luridus & M & $7 \times 10^{-6}$ & 3.18 & 0.96 & 198 & $12.5-22.6$ \\
\hline & & $\mathrm{F}$ & $6 \times 10^{-6}$ & 3.19 & 0.97 & 213 & $13.5-24.5$ \\
\hline & & $P$ & $6 \times 10^{-6}$ & 3.20 & 0.97 & 434 & $8.1-24.5$ \\
\hline Alexandria (Egypt) & S. rivulatus & $P$ & $22 \times 10^{-3}$ & 2.82 & 0.93 & 112 & $5.5-27.6$ \\
\hline Abdallah (2002) & S. luridus & $P$ & $11 \times 10^{-3}$ & 3.04 & 0.91 & 144 & $3.8-17$ \\
\hline Antalya (Turkey) & S. rivulatus & M & $7.94 \times 10^{-3}$ & 3.14 & 0.95 & 229 & 7.1-20.6 \\
\hline Bilecenoglu \& Kaya & & $\mathrm{F}$ & $6.43 \times 10^{-3}$ & 3.22 & 0.95 & 292 & $7-21.5$ \\
\hline$(2002)$ & & $P$ & $7.13 \times 10^{-5}$ & 3.18 & 0.95 & 521 & $7-21.5$ \\
\hline Junieh (Lebanon) & S. rivulatus & $\mathrm{P}$ & $0.71 \times 10^{-5}$ & 3.14 & $\times$ & 458 & $5-25.2$ \\
\hline Mouneimné (1978) & S. luridus & $\mathrm{P}$ & $0.67 \times 10^{-5}$ & 3.18 & $\times$ & 634 & $10.5-21.4$ \\
\hline \multicolumn{8}{|c|}{ Present study, central Mediterranean (Libyan coast) } \\
\hline East part & S. rivulatus & $P$ & $23.3 \times 10^{-3}$ & 2.82 & 0.93 & 1672 & $6.2-27.4$ \\
\hline West part and Sirt & S. luridus & $\mathrm{P}$ & $1.01 \times 10^{-3}$ & 3.23 & 0.96 & 1756 & $10.2-25.5$ \\
\hline
\end{tabular}

in this species. Bilecenoglu \& Kaya (2002) reported a maximum age of 8 years for individuals of $S$. rivulatus, with a total length of $20 \mathrm{~cm}$ for fish captured along the Turkish coast. This study used a different method involving scales, which may explain the different age structures found and support the hypothesis that scales are not an adequate method for the determination of age of siganid species. This hypothesis is also supported by the considerable overlapping of the length distributions of age groups (Bariche 2005). The validation of age reading for $S$. rivulatus has been performed by Bariche (2005) using the otoliths, and showed that one annulus only was formed during a calendar year along the Lebanon coast. El-Gammal (1988) used otolithometry to estimate the age of $S$. rivulatus in the Red Sea (El-Ghardaqa) and found a maximum age of 4-5 years, while Hashem (1983) reported a maximum age of 6 years for the same species in Saudi Arabia (Jeddah) using the Petersen method. These results are similar to studies performed by Mouneimné (1978) along the Lebanese coast using the same method; however they differed from studies in the Al-Ghardaqa region (Red Sea), probably due to variation in the maximum length and also the use of different methods for ageing.

The presented maximum theoretical length of $S$. rivulatus is slightly higher than the results from comparable studies in the Mediterranean Sea, Mouneimné (1978), Bilecenoglu \& Kaya (2002) and Bariche (2005); and similar to results from Red Sea population of $S$. rivulatus (El-Gammal 1988). The minimum growth of $S$. rivulatus observed was 0.04 by Mouneimné (1978). Other estimates vary between 0.23 by Kaya (2002) and 0.28 by 
Bariche (2005), which are larger than the presented estimates. Higher growth rates have been found in the Rea Sea at 0.43 by El-Gammal (1988). The phi-prime $(\Phi ')$ varied between 2.14 and 2.36 for $S$. rivulatus in the Mediterranean Sea, with a prediction of 1.49 based on the estimates by Mouneimné (1978). This is caused by the very low growth of 0.04 . The phi-prime $(\Phi ')$ of $S$. rivulatus in the Rea Sea was larger at 2.71 (El-Gammal 1988). These results suggest that the growth rates of $S$. rivulatus from the Libyan coast are similar to estimates from the eastern Mediterranean Sea.

The growth rate of S. luridus from the Libyan coast is similar to those from the eastern Mediterranean Sea Bariche (2005) and the phi-prime data ( $\left.\Phi^{\prime}\right)$ are 2.28 and 2.40 , respectively. The estimates by Mouneimné (1978) differ with a growth of 0.05 and a $\Phi$ '-value of 1.42. This variation in different growth rates might be due to the different habitats and the variability of food to these species where the samples were collected. Popper \& Gundermann (1975) report that the main reasons for differences in growth rates between populations of the same species in different areas is food habitats, difference of available algae and length of breeding period. These in turn might be due to temperature differences between the Mediterranean and Red Sea. The maximum theoretical weight was also different at $525.9 \mathrm{~g}$ for S. luridus and $424.3 \mathrm{~g}$ for $S$. rivulatus. Similarly, this variation may be due to differences in habitats of these species and also the fish conditions. Both species have established in their new environment, and have become regular in the Libyan catch.

\section{Acknowledgments}

We wish to express our gratitude to the staff of Marine Biology Research Centre (MBRC) in Libya and the Environment General Authority of Libya (EGA) for making available the laboratory and other facilities and our thanks to fishermen and fishermen unions of Libya for their collaboration, and to Laater $\mathrm{H}$. for her help. We would especially like to thank the referees for their comments and advices and Natasha Leaver for the linguistic revision of the text. This article is a part of the $\mathrm{Ph} \mathrm{D}$ Thesis made by Esmaile A. Shakman, Rostock University.

\section{Literature cited}

Allain V \& P Lorance. 2000. Age estimation and growth of some deep-sea fish from the northeast Atlantic Ocean. Cybium 24(3): 7-16.

Abdallah M. 2002. Length-weight relationship of fishes caught by trawl off Alexandria, Egypt. Naga ICLARM Q 25: 1920.
Bariche M. 2005. Age and growth of Lessepsian rabbitfish from the eastern Mediterranean. Journal of Applied Ichthyology 21: 141-151.

Bariche M, Y Letourneur \& MH Vivien. 2004. Temporal fluctuations and settlement patterns of native and Lessepsian herbivorous fishes on the Lebanese coast (eastern Mediterranean). Environmental Biology of Fishes 70: 8190.

Bariche M, MH Vivien \& JP Quignard. 2003. Reproductive cycles and spawning periods of two Lessepsian Siganid fishes on the Lebanese coast. Journal of Fish Biology 62: 129-142.

Bilecenoglu M \& M Kaya. 2002. Growth of marbled spinefoot Siganus rivulatus Forsskål, 1775 (Teleostei: Siganidae) introduced to Antalya Bay, eastern Mediterranean Sea (Turkey). Fisheries Research 54: 279-285.

Bilecenoglu M \& E Taskavak. 2002. Characterization of Lessepsian migrant fish at Turkish sea. In: Bayram Ö \& N Basusta (eds). Workshop on Lessepsian migration, 20-21 July 2002 Gökceada- Turkey, pp. 87-91.

Boeuf G \& P Payan. 2001. How should salinity influence fish growth? Comparative Biochemistry and Physiology Part C: Toxicology \& Pharmacology 130(4): 411-423.

Campana SE. 1990. How reliable are growth back-calculations based on otoliths?. Canadian Journal of Fisheries and Aquatic Sciences 47: 2219-2227.

El-Gammal FI. 1988. Age, growth and mortality of the rabbitfish Siganus rivulatus (Forsk., 1975) from the Red Sea. Bulletin of the Institute of Oceanography and Fisheries (ARE) 14: 13-21.

Froese R \& D Pauly. 2004. Fishbase 2004. [Online version]: $<$ http://www.fishbase.org. $>$.

Gaumet F, G Boeuf, A Severe, A Le Roux \& N Mayer-Gostan. 1995. Effects of salinity on the ionic balance and growth of juvenile turbot. Journal of Fish Biology 47: 865-876.

Golani D. 1993. Trophic adaptation of Red Sea fishes to the eastern Mediterranean environment-review and new data. Israel Journal of Zoology 39: 391-402.

Golani D. 1990. Environmentally-induced meristic change in Lessepsian fish migrants, a comparison of source and colonizing populations. Bulletin de l'Institut Océanographique de Monaco 7: 143-152.

Hashem MT. 1983. Biological studies on Siganus rivulatus (Forsk.) in the Red Sea. Journal of the Faculty of Marine Science, Jeddah 3: 119-127.

King RP. 1996. Length-weight relationships of Nigerian freshwater fishes. Naga: The ICLARM Quarterly 19(3): 4952.

Ktari F \& MH Ktari. 1974. Presence dans le Golf de Gabes de Siganus luridus (Rüppel, 1829) et de Siganus rivulatus (Forsskal, 1775) (Poissons, Siganidae) parasites par Pseudohaliotrematodides polymorphus. Bulletin de 1'Institut National Scientifique et Technique d'Océanographie et de Pêche de Salammbô 3(1-4): 95-98. 
Mouneimné N. 1978. Poissons des côtes du Liban (Méditerranée Orientale), biologie et pêche. Thèse de Doctorat d'Etat ès-Sciences Naturelles, Université Pierre et Marie Curie (Paris VI), Paris, 490 pp.

Pauly D \& JL Munro. 1984. Once more on the comparison of growth in fish and invertebrates. ICLARM Fishbyte 2: 21 .

Popper D \& N Gundermann. 1975. Some ecological and behavioural aspects of Siganid populations in the Red Sea and Mediterranean coasts of Israel in relation to their suitability for aquaculture. Aquaculture 6: 127-141.

Popper D, R Pitt \& Y Zohar. 1979. Experiments on the propagation of Red Sea Siganids and some notes on their reproduction in nature. Aquaculture 16: 177-181.

Ricker WE. 1973. Linear regressions in fishery research. Journal of the Fisheries Research Board of Canada 30: 409434.

Ricker WE. 1975. Computation and interpretation of biological statistics of fish populations. Bulletin of the Fisheries Research Board of Canada 191: 1-382.

Saoud P, S Kreydiyyeh, A Chalfoun \& M Fakih. 2007. Influence of salinity on survival, growth, plasma osmolality and gill $\mathrm{Na}^{+}-\mathrm{K}^{+}$- ATPase activity in the rabbitfish Siganus rivulatus. Journal of Experimental Marine Biology and Ecology 348: 183-190.
Shakman EA \& R Kinzelbach. 2007. Distribution and characterization of Lessepsian migrant fish along the coast of Libya. Acta Ichthyologica et Piscatoria 37(1): 7-15.

Spiegel MR. 1991. Théorie et applications de la statistique, 358 pp. McGraw-Hill, Paris.

Statgraphics. 2005. Statgraphics Centurion XV User Manual, 286 pp. StatPoint, Herndon.

Stirn J. 1970. Some note on western trends of Lessepsian migration. Journées Ichthyologiques, Rome, 30 Nov-1 Dec, CIESM, Mónaco, pp. 187-190.

Streftaris N, A Zenetos \& E Papathanassiou. 2005. Globalisation in marine ecosystem: The story of NonIndigenous marine species across European Seas. Oceanography and Marine Biology: An Annual Review 43: 419-453.

Suresh VR, BK Biswas, GK Vinci, K Mitra \& A Mukherjee. 2006. Biology and fishery of barred spiny eel, Macrognathus pancalus Hamilton. Acta Ichthyologica et Piscatoria 36(1): 31-37.

Von Bertalanffy L. 1938. A quantitative theory of organic growth. Human Biology 10: 181-213.

Recibido el 3 de diciembre de 2007 y aceptado el 19 de agosto de 2008 